\title{
Improvement of enzyme stability via non-covalent complex formation with dextran against temperature and storage lifetime
}

\author{
Melda Altikatoglu ${ }^{*}$, Huriye Kuzu² \\ ${ }^{1}$ Yildiz Technical University, Faculty of Arts and Sciences, Department of Chemistry, Davutpasa Campus 34210 Esenler, \\ Istanbul/TURKEY \\ ${ }^{2}$ Yildiz Technical University, Faculty of Chemical and Metallurgical Engineering, Department of Bioengineering, Davutpasa \\ Campus 34210 Esenler, Istanbul/TURKEY \\ *Corresponding Author: Dr. Melda Altikatoglu, e-mail: maltikatoglu@yahoo.com
}

\begin{abstract}
The optimal methodology to prepare the novel modified enzyme, polymer-enzyme complex, was developed to give a high catalytic activity in aqueous solution. The non-covalent complexes of two different enzymes (horseradish peroxidase and glucose oxidase) were prepared with various molar ratios $\left(\mathrm{n}_{\mathrm{D}} / \mathrm{n}_{\mathrm{E}} 0,05 ; 0,1 ; 1\right.$; $5 ; 10 ; 15 ; 20)$ by using $75 \mathrm{kDa}$ dextran. The thermal stabilities of the obtained complexes were evaluated with the activities determined at different temperatures $\left(25,30,35,40,50,60,70,80^{\circ} \mathrm{C}\right)$ applying 60 minutes incubation time for $\mathrm{pH}$ 7. The complexes with the molar ratio $\mathrm{n}_{\mathrm{D}} / \mathrm{n}_{\mathrm{HRP}}: 10$ and $\mathrm{n}_{\mathrm{D}} / \mathrm{n}_{\mathrm{GOD}}: 5$ showed the highest thermal stability. Its activity was very high ( $c a$. 1,5-fold higher activity than pure enzyme for HRP-dextran complexes) and almost the same between applying one hour incubation time and without incubation, and could also be measured at high temperatures $\left(70,80^{\circ} \mathrm{C}\right)$. We finally succeeded in preparing dextran-enzyme complexes which showed higher activity than pure enzyme in aqueos solution at all temperatures for $\mathrm{pH} 7$. In addition, the mentioned complexes at $\mathrm{pH} 7$ had very long storage lifetime compared to purified enzyme at $+4{ }^{\circ} \mathrm{C}$; which is considered as a good feature for the usage in practice.
\end{abstract}

Keywords: Thermal stabilization, Complex, Enzyme, Dextran, storage lifetime

\section{INTRODUCTION}

Protein-polysaccharide complexes are also important in industrial applications such as micro- and nano-encapsulation processes ${ }^{1-4}$, the design of multi-layers structures, the formation and the stabilization of food emulsions ${ }^{6}$, the formation of new food gels ${ }^{\mathbf{1 2}}$ and the recovery of proteins from industrial by-products ${ }^{\mathbf{8}-10}$. Supra-molecular structures formed by non-covalent interactions between protein and polysaccharides (complexes, aggregated complexes and coacervates) have represented a very active research area in the last $3-4$ years. The formation of complexes between neutral biopolymers is less studied, but the curiosity of scientists should modify this situation in the next few years ${ }^{11,12}$.

Depending on biopolymer pairs considered, the thermal stability of enzymes can be improved or impaired. It was supposed that such stabilization could be due to the formation of a network of aggregated proteins with the polysaccharides trapped inside ${ }^{\mathbf{1 3}, \mathbf{1 4}}$. The chemical modification with polymers using laborious procedures leads to the loss of enzyme activity. On the other hand, the noncovalently-formed complex of an enzyme with polymers such as alkylated poly(ethyleneimine $)^{\mathbf{1 5}}$, sugar-based polymers $^{\mathbf{1 6}}$, polystyrene ${ }^{17}$, poly(ethylene glycol) (PEG) with a high molecular weight $(30-100 \mathrm{kDa})$ has been proposed as an alternative modified enzyme ${ }^{\mathbf{1 8}}$.

Dextran is a complex, branched polysaccharide that can be synthesized from sucrose by enzymes or can also be produced by bacteria and yeast. Dextran has been used as blood plasma substitute, packing material in column chromatography, and delivery vehicle of drugs due to its good biocompatibility (Fig. 1) 19, 20, 21.

Horseradish peroxidase is used as a reagent for organic synthesis and biotransformation as well as in coupled enzyme assays, chemiluminescent assays, immunoassays and the treatment of waste waters. Improvements to desir-

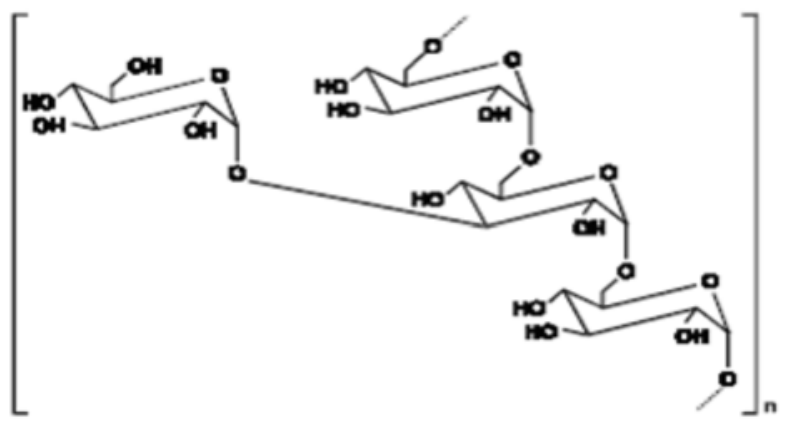

Figure 1. Structure of dextran

able qualities of the enzyme such as its relatively good stability in aqueous and non-aqueous solvent systems are actively sought as an outcome of chemical modification, sitedirected mutagenesis and directed evolution studies ${ }^{22,23}$. GOD is used in large scale technological applications, which includes removing of residual glucose and oxygen from beverages, wine and foodstuff, in bleaching cellulose fibres, production of gluconic acid and also used as a food preservative $^{13,15,16}$. However, the most significant GOD application is in biosensors for the monitoring of glucose levels in body fluids, during the fermentation of beverages or in miniaturized biofuel cells $\mathbf{2 4}^{\mathbf{2 6}}$.

The advantages of employing high temperature are as follows: higher process rates (reaction temperature increase from 25 to $75{ }^{\circ} \mathrm{C}$ will result in about a 100 -fold increase in the process rate), fewer diffusional limitations and lower viscosity of the medium, decreased bacterial contamination (which is of paramount importance in food and pharmaceutical industry) and a shift in thermodynamic equilibrium in case of endothermic reactions. Thus, there is always a need for enzymes active in extremes of temperature ${ }^{27}$.

Non-covalent enzyme-dextran complexes have been reported by de la Casa et al. ${ }^{\mathbf{2 8}, \mathbf{2 9}}$. They have been analyzed 
as the effect of the modification by dextrans of the microenvironment of Candida rugosa lipase. In this study, the non-covalently-formed complexes of HRP and GOD with dextran have been proposed as an alternative modified enzyme towards industrial application and storage stability. We found that the molar ratio of the polymer/ enzyme in the preparation stage governed the activity of the polymer-enzyme complex. The stabilities of the complexes towards temperature were evaluated with the activities determined at different temperatures using one hour incubation time. In addition, storage lifetimes of purified enzymes and the complexes with $\mathrm{n}_{\mathrm{D}} / \mathrm{n}_{\mathrm{HRP}}: 10$; $\mathrm{n}_{\mathrm{D}} / \mathrm{n}_{\mathrm{GOD}}: 5$, respectively, were studied.

\section{MATERIAL AND METHODS}

\section{Materials}

Horseradish Peroxidase (E.C. 1.11.1.7) $(\mathrm{Mw} \sim 40.000$ Da) and o-dianisidine were purchased from Fluka. Concanavalin A-Sepharose 4B column material and dextran from Leuconostoc mesenteroides $\left(\mathrm{M}_{\mathrm{w}} 75.000 \mathrm{Da}\right)$ were obtained from Sigma Chemical Co. (St. Louis, MO). The regenerated Cellulose membrane was purchased from Millipore (Dia 25mm, NMWL 10.000). All other chemicals used were of analytical grade. The ultra pure water was obtained from Millipore MilliQ Gradient system.

\section{Enzyme purification procedure}

HPLC chromatograms of the purchased HRP (Fluka) and GOD (Fluka) showed that there were impurities in this type of commercial enzymes. In order to synthesize the complexes, it was decided that using purified enzymes would be better for this study. The purchased HRP was purified by Affinity Chromatography using Concanavalin A-Sepharose 4B (con A-Sepharose 4B) as column material. In order to remove all the unbound impurities, the column was washed with $0.1 \mathrm{M}$ acetate buffer, $\mathrm{pH} 6$ containing $0.1 \mathrm{M} \mathrm{NaCl}, 1 \mathrm{mM} \mathrm{CaCl}$ and $1 \mathrm{mM} \mathrm{MnCl}_{2}$. To elute the enzyme which was bound to the column material, the column was washed with $0.1 \mathrm{M}$ acetate buffer, $\mathrm{pH}$ 6 containing $0.1 \mathrm{M}$ methyl- $\alpha$-D-mannopyranoside and the fractions were collected ${ }^{31,32}$. Absorbances at 280 and 403 $\mathrm{nm}$ were measured with UV spectrophotometer and the $R Z$ values $\left(\mathrm{A}_{460} / \mathrm{A}_{280}\right)$ for the purified and commercial enzymes were calculated. The RZ value for the purified HRP was 2.1 whereas the RZ value of the purchased enzyme was only 0.85 . The purified enzyme was concentrated in the ultra-filtration cell with the Regenerated Cellulose membrane (Dia 25mm, Mw 10.000) by washing 2 times with distilled water and 2 times with $0.01 \mathrm{M}$ PBS and $\mathrm{pH} 7$ buffer. The RZ value of the enzyme was determined as 2.24 .

The purchased GOD was purified by Gel-permeation Chromatography using Sephadex G-50 column. For the elution, the column was washed with PBS and the fractions were collected in tubes. The absorbances at $280 \mathrm{~nm}$ were measured with a UV spectrophotometer and appropriate fractions were pooled for the complex synthesis.

\section{Preparation of HRP-Dextran aldehyde conjugates}

For synthesizing enzyme-polymer complexes, an appropriate amount of dextran was calculated by making en- zyme amount $(0.1 \mathrm{mg} / \mathrm{ml}$ for HRP and $0.2 \mathrm{mg} / \mathrm{ml}$ for GOD) constant according to the formula given below:

$$
\frac{n_{D}}{n_{E}}=\frac{C_{D} M_{E}}{C_{E} M_{D}}=0,05 ; 0,1 ; 1 ; 5 ; 10 ; 15 ; 20
$$

The calculated amounts of dextran for the mentioned ratios were dissolved in the phosphate buffer, $\mathrm{pH} 7$ as well as the purified enzyme. The reaction was initiated by mixing enzyme $(2 \mathrm{ml})$ and dextran $(2 \mathrm{ml})$ solutions together and incubation continued for 16 hours at $25^{\circ} \mathrm{C}$.

\section{Activity assay of HRP}

The test tubes containing $885 \mu \mathrm{l}$ PBS buffer were incubated in stirred water baths at working temperatures in order to adjust the temperatures. The reaction was started by adding $20 \mu \mathrm{l}$ o-dianisidine, $10 \mu \mathrm{l}$ enzyme solution and finally $10 \mu$ l hydrogen peroxide as the initiator to the test tube respectively. After 10 minutes, the reaction was stopped by adding $75 \mu \mathrm{l} 1 \mathrm{M} \mathrm{NaOH}$ to reaction media and $\mathrm{A}_{460}$ values were recorded. The total activity in the units was calculated with these absorbance values ${ }^{33}$.

$$
\begin{aligned}
& \mathrm{U} / \mathrm{mg}= \mathrm{A}_{460} \cdot 10^{6} \\
& \varepsilon \cdot \mathrm{t} \cdot \mathrm{c}_{\mathrm{HRP}}
\end{aligned}
$$

$\varepsilon$ : Molar absorption coefficient of o-dianisidine (11.300 $\mathrm{M}^{-1} \mathrm{~cm}^{-1}$ )

$\mathrm{t}$ : Incubation time (10 minute)

$\mathrm{C}_{\mathrm{HRP}}$ : HRP concentration $(0.0025 \mathrm{mg} / \mathrm{ml})$

$\mathrm{A}_{460}$ : Absorbance at $460 \mathrm{~nm}$

Thermal and storage stabilities of pure enzyme and complexes were evaluated with the activities determined according to the procedure described above. But in the thermal stability procedure enzyme and complex solutions were kept at different working temperatures for 60 minutes in water baths and activity determination was performed afterwards at $\mathrm{pH}$ 7. The storage stability (lifetimes) of the purified enzyme and the complex with $\mathrm{n}_{\mathrm{D}} / \mathrm{n}_{\mathrm{HRP}} 10$ were studied for $+4^{\circ} \mathrm{C}$ at $\mathrm{pH} 7$.

\section{Activity assay of GOD}

The test tubes containing $780 \mu \mathrm{l}$ PBS buffer were incubated in stirred water baths at working temperatures for 5 minutes. The reaction was started at working temperatures $\left(25,30,35,40,50,60,70^{\circ} \mathrm{C}\right)$ by adding respectively $50 \mu$ l glucose $(\% 25 \mathrm{w} / \mathrm{v}), 25 \mu \mathrm{l}$ o-dianisidin $(10 \mathrm{mM}), 15$ $\mu \mathrm{l} \mathrm{HRP}(0.005 \mathrm{mg} / \mathrm{ml})$ and $30 \mu \mathrm{l} \mathrm{GOD}$ solution $(0.0025$ $\mathrm{mg} / \mathrm{ml}$ ) as the initiator of this reaction. After 10 minutes, the reaction was stopped with the $100 \mu \mathrm{l} 2 \mathrm{M} \mathrm{H}_{2} \mathrm{SO}_{4}$ solution and in the meantime the total volume was completed to $1 \mathrm{ml}^{23,27}$. Afterwards the UV spectra of these reaction-products were taken and the A400 values of the products were recorded. The activities in the units were calculated with these absorbance values according to the formula given below.

$\mathrm{U} / \mathrm{mg}=A_{400} \mathrm{x} 10^{6} / \varepsilon t c_{\mathrm{GOD}}$

$\varepsilon$ : Molar absorption coefficient of o-dianisidine at 400 $\mathrm{nm}\left(17.500 \mathrm{M}^{-1} \mathrm{~cm}^{-1}\right)$

$t:$ Incubation time (10 minute)

$c_{\mathrm{GOD}}$ : GOD concentration $(0.0025 \mathrm{mg} / \mathrm{ml})$

$A_{400}:$ Absorbance at $400 \mathrm{~nm}$

The stabilities of the complexes and the purified GOD were determined according to the same procedure for the 
activity determination described above. But in this procedure enzyme and complex solutions were kept at different working temperatures for one hour in water baths and the activity determination was performed afterwards at $\mathrm{pH} 7$. The storage stability (lifetimes) of the purified enzyme and the complex with $\mathrm{n}_{\mathrm{D}} / \mathrm{n}_{\mathrm{GOD}} 5$ were studied for $+4^{\circ} \mathrm{C}$ at $\mathrm{pH} 7$.

\section{Characterization of the complex with GPC (Gel-Permea- tion Chromatography)}

The molecular weight distributions of dextran, purified enzyme and complexes with the ratio $\mathrm{n}_{\mathrm{D}} / \mathrm{n}_{\mathrm{HRP}}$ : 10 and $\mathrm{n}_{\mathrm{D}} /$ $\mathrm{n}_{\mathrm{GOD}}: 5$ were determined by gel-permeation chromatography (Viscotek GPCmax VE2001 GPC Solvent/sample module) on a 7,9mm x $50 \mathrm{~cm}$ Shim-Pack Diol $300 \mathrm{col}-$ umn with UV detector. The fractions were eluated at 1 ml.min ${ }^{-1}$ with $0,1 \mathrm{M}$ PBS buffer $(\mathrm{pH} 7)$ containing 0,15 $\mathrm{M} \mathrm{NaCl}$ and 7,5 $\mathrm{mM} \mathrm{NaN}_{3}$.

\section{RESULTS AND DISCUSSION}

We obtained several complexes composed of two different enzymes (HRP and GOD) and dextrans with different enzyme/dextran (w/w) ratios. Gel permeating chromatography has been a widely used technique for estimating these characteristics of proteins, polysaccharides, protein-polymer conjugates in their native forms based on their elution positions ${ }^{34}, 35$. The size exclusion chromatograms of the enzyme-dextran complexes $\left(\mathrm{n}_{\mathrm{D}} / \mathrm{n}_{\mathrm{HRP}} 10\right.$ and $\left.\mathrm{n}_{\mathrm{D}} / \mathrm{n}_{\mathrm{GOD}} 5\right)$, purified enzyme and dextran recorded by using ultraviolet (UV) detectors (Fig.2). The
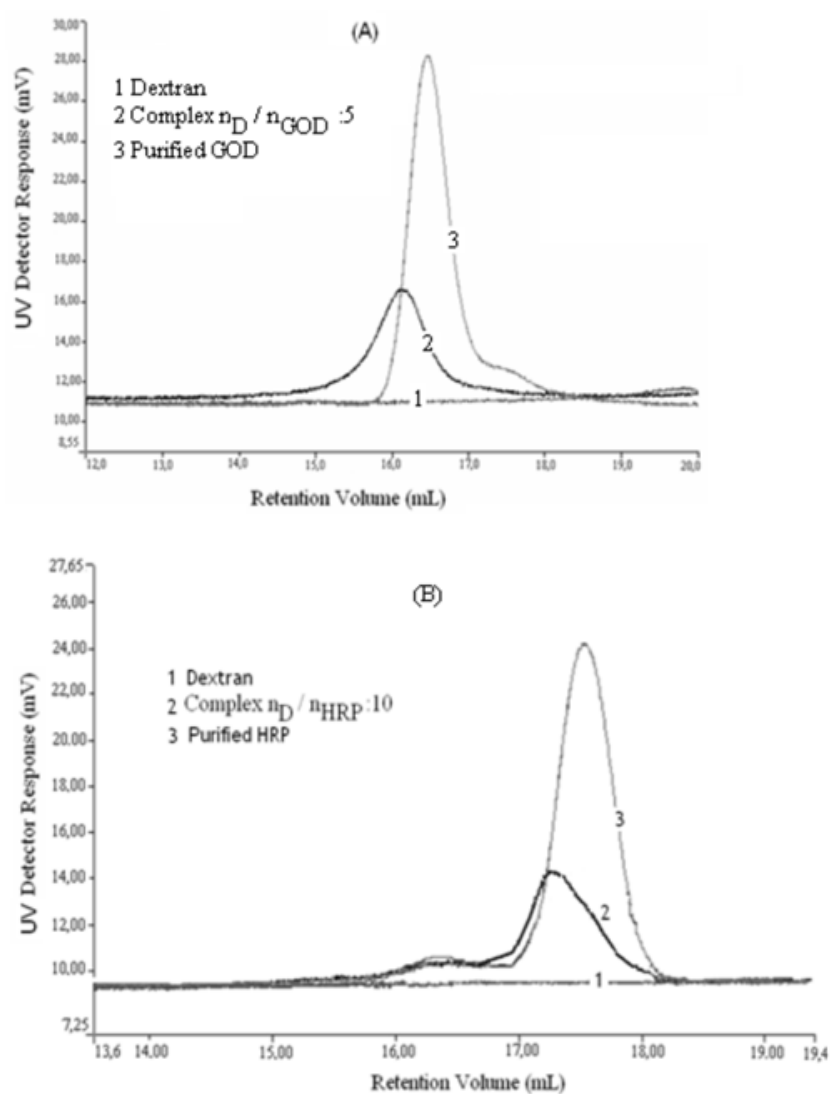

Figure 2. The chromatograms of dextran-enzyme complex and purified enzyme with UV detector: (A) Dextran-HRP complex $\left(\mathrm{n}_{\mathrm{D}} / \mathrm{n}_{\text {HRP }} 10\right)$ and purified HRP, (B) Dextran-GOD complex $\left(\mathrm{n}_{\mathrm{D}} / \mathrm{n}_{\mathrm{GOD}} 5\right)$ and purified GOD

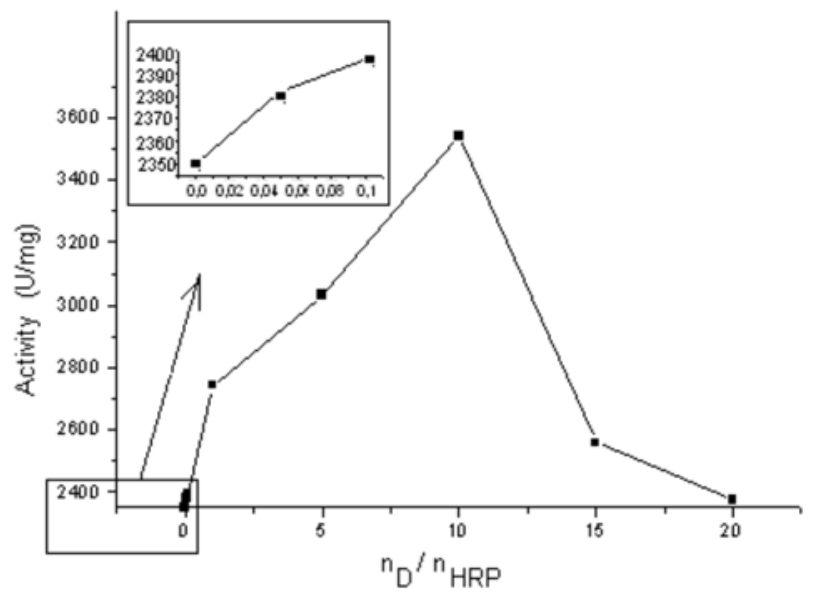

Figure 3. The activities of HRP and complexes as a function of coupling ratio at $\mathrm{pH} 7 ; 25^{\circ} \mathrm{C} ; \mathrm{c}_{\mathrm{HRP}}=0,1 \mathrm{mg} / \mathrm{ml}$ ( 0 point is pure enzyme)

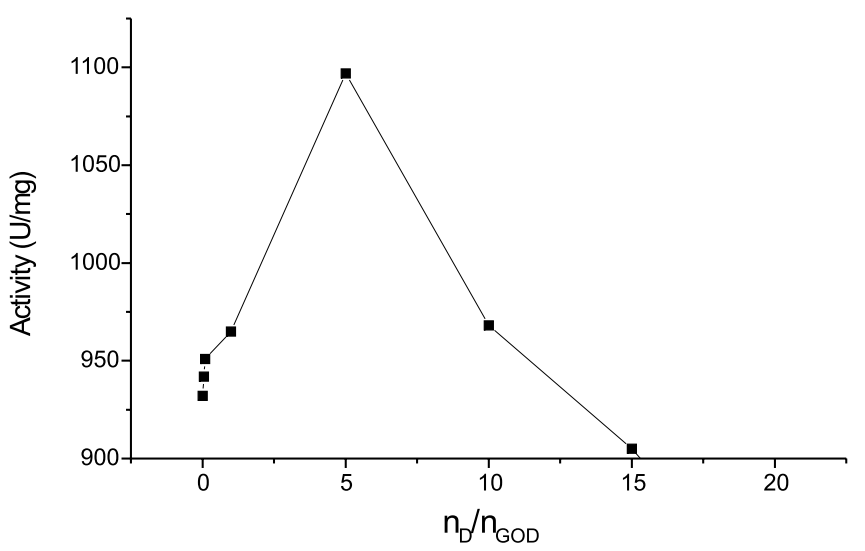

Figure 4. The activities of GOD and complexes as a function of coupling ratio at $\mathrm{pH} 7 ; 25^{\circ} \mathrm{C} ; \mathrm{c}_{\mathrm{HRP}}=0,1 \mathrm{mg} /$ $\mathrm{ml}$ ( 0 point is pure enzyme)

eluation position of the complexes which was placed in front of enzyme and dextran, relates the formation of macromolecules with higher molecular weight than the constituents.

In order to improve the activity of enzymes, dextranHRP and dextran-GOD complexes using different molar ratios $\left(\mathrm{n}_{\mathrm{D}} / \mathrm{n}_{\mathrm{E}} 0.05 ; 0.1 ; 1 ; 5 ; 10 ; 15 ; 20\right)$ were prepared. Figure 3 and 4 present the dependence of the activity of the dextran-HRP and dextran-GOD mixtures, respectively, on the amount of added polymer at the constant concentration of the enzyme. The complexes $\mathrm{n}_{\mathrm{D}} / \mathrm{n}_{\mathrm{HRP}}: 10$ and $\mathrm{n}_{\mathrm{D}} /$ $\mathrm{n}_{\mathrm{GOD}}: 5$ showed higher activity than other complexes and pure enzyme.

To reveal the thermal stabilities of the complexes more clearly, the activities of the complexes and the purified enzyme were determined applying a one-hour incubation time (the solutions were kept at different working temperatures for 60 minutes in water baths) and without incubation at different temperatures for $\mathrm{pH} 7$ (Figure 5 and $6)$. Figure 5 demonstrates that the complexes of dextranHRP showed much higher activity than the purified enzyme at all temperatures. The complexes with the ratio $\mathrm{n}_{\mathrm{D}} / \mathrm{n}_{\mathrm{HRP}}=1 ; 5 ; 10$ only had activities at $80^{\circ} \mathrm{C}$. As it is shown in Figure 4B, the activity decline of the purified enzyme was very fast with the increase in temperature when 60 minutes of incubation were applied. Whereas the 

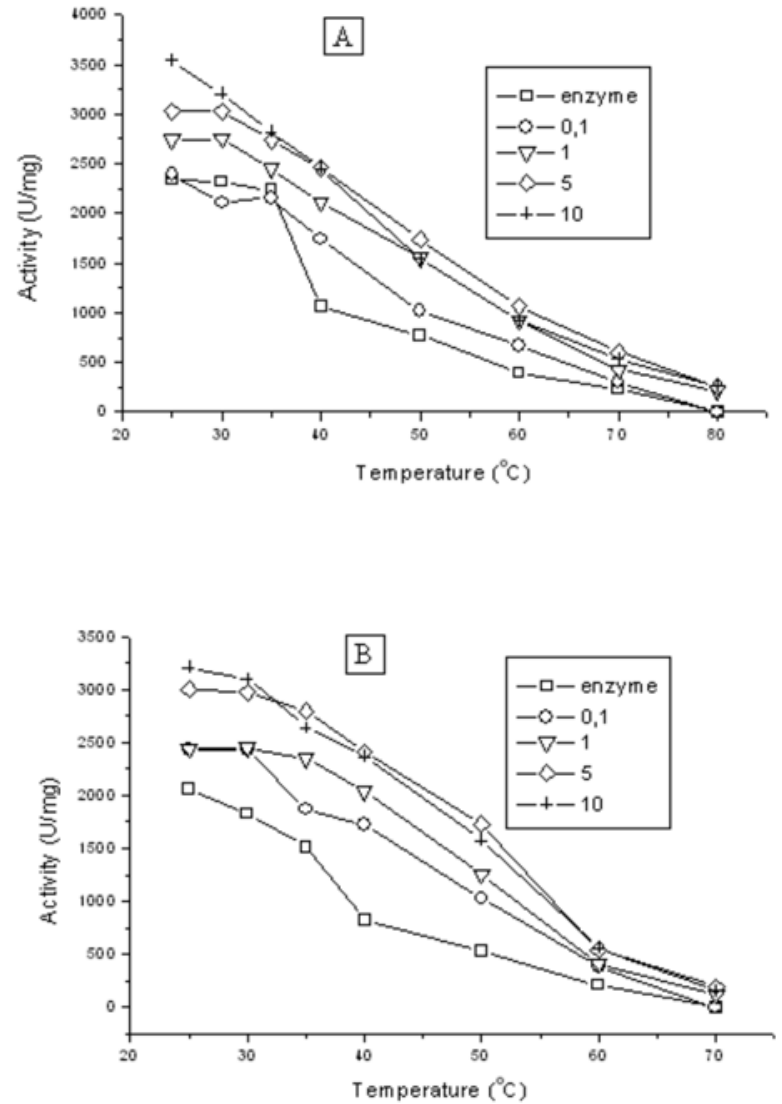

Figure 5. Thermal stabilities of dextran-HRP complexes with different molar ratios at $\mathrm{pH}$ 7: (A) activity determination without incubation, (B) activity determination with 60 minutes incubation at working temperature

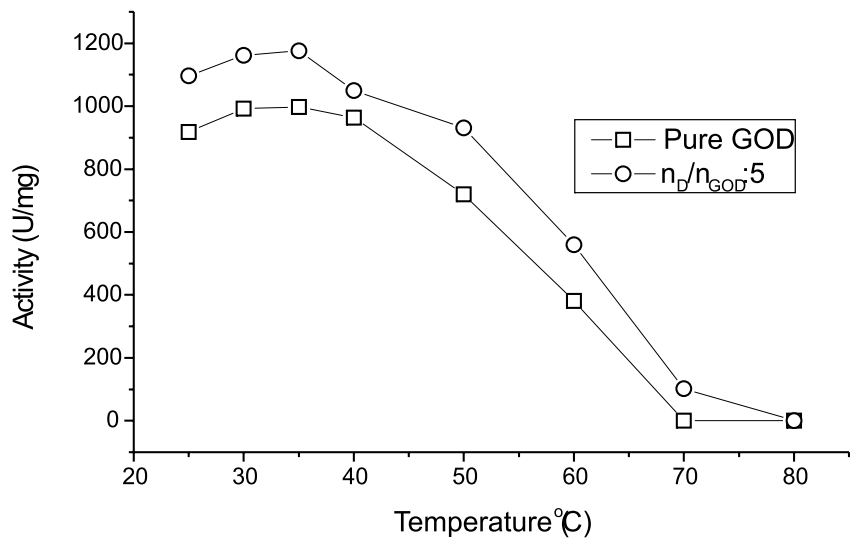

Figure 6. Thermal stabilities of dextran-GOD complex and purified GOD at $\mathrm{pH} 7$; activity determination with 60 minutes incubation at working temperature

complexes had higher resistance against the temperature. Especially, the activities of the complexes with the ratio $\mathrm{n}_{\mathrm{D}} / \mathrm{n}_{\mathrm{HRP}}=5 ; 10$ were not changed significantly with and without the incubation at different temperatures.(the complex $\mathrm{n}_{\mathrm{D}} / \mathrm{n}_{\mathrm{HRP}}: 10$ showed highest activity all temperatures.)

As demonstrated in Figure 6, complex $\mathrm{n}_{\mathrm{D}} / \mathrm{n}_{\mathrm{GOD}}: 5$ showed much higher activity than the purified GOD at all temperatures, which demonstrates activity also at $70^{\circ} \mathrm{C}$, when 60 minutes of incubation were applied.

Figure 7 and 8 show the storage lifetimes of dextran$\operatorname{HRP}\left(\mathrm{n}_{\mathrm{D}} / \mathrm{n}_{\mathrm{HRP}}: 10\right)$ and dextran-GOD $\left(\mathrm{n}_{\mathrm{D}} / \mathrm{n}_{\mathrm{GOD}}: 5\right)$ complexes at $\mathrm{pH} \mathrm{7,} \mathrm{respectively.} \mathrm{The} \mathrm{purified} \mathrm{HRP} \mathrm{lost} \mathrm{its}$ activity after 14 days at $+4^{\circ} \mathrm{C}$. However, complex $\left(\mathrm{n}_{\mathrm{D}} / \mathrm{n}_{\mathrm{HRP}}: 10\right)$ was stable, showing good activity values for 80 days at $+4^{\circ} \mathrm{C}$ (Figure 7). Similarly, the complex with the ratio $\mathrm{n}_{\mathrm{D}} / \mathrm{n}_{\mathrm{GOD}}: 5$ was stable, showing good activity values for 83 days at $+4^{\circ} \mathrm{C}$ (Figure 8 ). As a result, these complexes had both higher activity and a longer storage lifetime compared to the purified at $+4^{\circ} \mathrm{C}$; which is considered as a good feature for usage in practice.

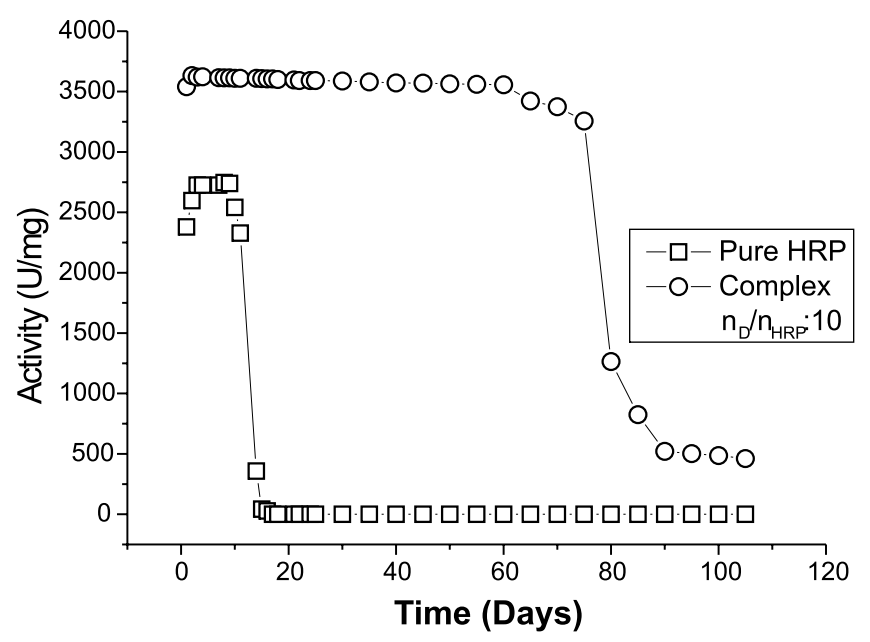

Figure 7. Storage lifetimes of the purified HRP and the complex with $\mathrm{n}_{\mathrm{D}} / \mathrm{n}_{\mathrm{HRP}}: 10$ at $+4 \mathrm{oC}$. (Three consecutive activity measurements were carried out for each day and were averaged)

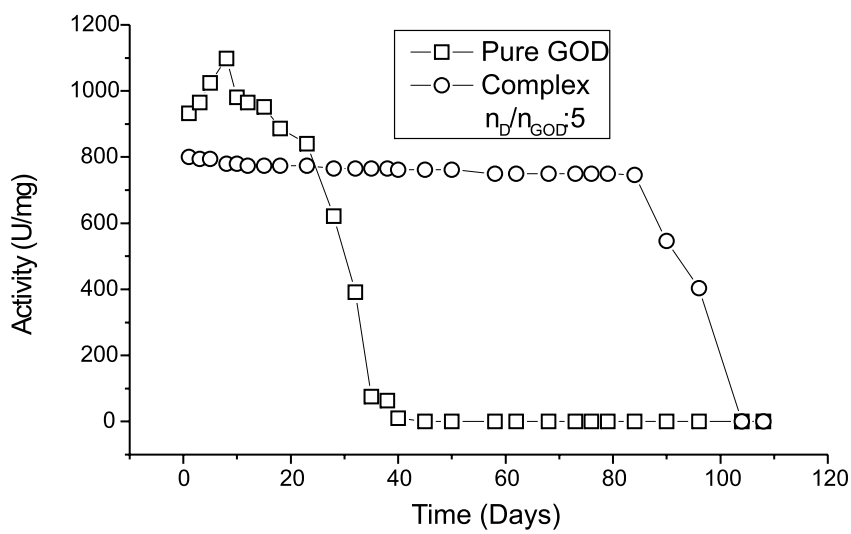

Figure 8. Storage lifetimes of the purified GOD and the complex with $\mathrm{n}_{\mathrm{D}} / \mathrm{n}_{\mathrm{GOD}}: 5$ at $+4 \mathrm{oC}$. (Three consecutive activity measurements were carried out for each day and were averaged)

\section{CONCLUSION}

The possibility to stabilize enzyme-polysaccharide complexes by physical treatments is really important from an industrial application point of view. The treatment itself was very easy and low-cost in terms of activity and provides enormous advantages for the enzymes that are going to be used in long-storage required systems. The preparation of complexes dextran-enzyme provided an enhanced stability for the two enzymes against temperature and storage. In fact, although it was not thoroughly investigated, the non-covalent bonding of the HRP and GOD with dextran showed quite higher activity than the purified enzyme at all temperatures and seemed to be stabilizing related to time. These results should be of general applicability to other enzymes or polymers interaction, and solve an important problem in any system where 
long-time storing, low enzyme concentration, high temperation, etc. may be necessary. This study will develop along several lines, namely further elaboration of theoretical concepts of polyreactions, biomodelling and construction of stable polyenzyme preparations.

\section{LITERATURE CITED}

1. Xing, F., Cheng, G., Yang, B. \& Ma, L., (2004). Microencapsulation of capsaicin by complex coacervation of gelatine Acacia, and tannins. J Appl Polym Sci. 91, 2669 - 2675. DOI: 10.1002/app.13449.

2. Xing, F., Cheng, G., Yang, B. \& Ma, L., (2005). Nanoencapsulation of capsaicin by complex coacervation of gelatine, Acacia, and tannins. J Appl Polym Sci. 96, 2225 2229. DOI: $10.1002 /$ app. 21698

3. Champagne, C.P. \& Fustier, P., (2007). Microencapsulation for the improved delivery of bioactive compounds into foods. Curr Opin Biotechnol. 18:184-90. DOI: 10.1016/j.copbio.2007.03.001

4. Turgeon, S.L., et al. (2007). Protein-polysaccharide complexes and coacervates. Current Opinion in Colloid \& Interface Science 12, 166 - 178. DOI: 10.1016/j.cocis.2007.07.007.

5. Daniel, S.K., (2007). Microparticles and nanoparticles for drug delivery. Biotechnol Bioeng. 96, 203 - 209. DOI: 10.1002/bit.21301.

6. Dickinson, E., (2006). Colloid science of mixed ingredients. Soft Matter 2, 642 - 652. DOI: 10.1039/b605670a.

7. Haug, I.J., Draget, K.I. \& Smidsrod, O., (2004). Physical behaviour of fish gelatin-א-carrageenan mixtures. Carbohydr Polym. 56, 11 - 19. DOI: 10.1016/j.carbpol.2003.10.014.

8. Vikelouda, M. \& Kiosseoglou, V., (2004). The use of carboxymethylcellulose to recover potato proteins and control their functional properties. Food Hydrocoll 18, 21 - 27. DOI: $10.1016 /$ S0268-005X(03)00038-9.

9. Damianou, K. \& Kiosseoglou, V., (2006). Stability of emulsions containing a whey protein concentrate obtained from milk serum through carboxymethylcellulose complexation. Food Hydrocoll 20, 793 - 799. DOI:10.1016/j.foodhyd.2005.07.011.

10. Montilla, A., Casal, E., Moreno, J., Belloque, J., Olano, A. \& Corzo, N., (2007). Isolation of bovine B-lactoglobulin from complexes with chitosan. Int Dairy J. 17, 459 - 464. DOI:10.1016/j.idairyj.2006.05.009.

11. Turgeon, S.L., Beaulieu, M., Schmitt, C. \& Sanchez, C., (2007). Protein-polysaccharide interactions: phase-ordering kinetics, thermodynamic and structural aspects. Current Opinion in Colloid \& Interface Science 8, 401 - 414. DOI: 10.1016/S1359-0294(03)00093-1.

12. Doublier, J.L., Garnier, C., Renard, D. \& Sanchez, C., (2000). Protein-polysaccharide interactions. Curr Opin Colloid Interface Sci. 5, 202 - 214. DOI: 10.1016/S1359-0294(00)00054-6.

13. de Kruif, C.G., Weinbreck, F., de Vries, R., (2004). Complex coacervation of proteins and anionic polysaccharides. Curr Opin Colloid Interface Sci. 9, 340 - 349. DOI: 10.1016/j.cocis.2004.09.006.

14. Murakami, Y. \& Hirata, A., (1999). Poly(Ethylene Glycol)- $\alpha$-Chymotrypsin Complex Catalytically Active in Anhydrous Isooctane. Journal of Bioscience and Bioengineering 88, 441 - 443. DOI: 10.1016/S1389-1723(99)80224-2.

15. Blinkovsky, A.M., Khmelnitsky, Y.L. \& Dordick, J.S., (1994). Organosoluble enzyme-polymer complexes: A novel type of biocatalyst for non-aqueous media. Biotechnol. Tech. 8, 33 - 38. DOI: 10.1007/BF00207630.

16. Otamiri, M., Adlercreutz, P. \& Mattiasson, B., (1992). Complex formation between chymotrypsin and ethyl cellulose as a means to solubilize the enzyme in active form in toluene. Biocatalysis 6, 291 - 305. DOI: 10.3109/10242429209065249.

17. Otamiri, M., Adlercreutz, P. \& Mattiasson, B., (1994). Polymer-polymer organic solvent two-phase system: A new type of reaction medium for bioorganic synthesis. Biotechnol. Bioeng. 43, 987 - 994. DOI: 10.1002/bit.260431012.
18. Murakami, Y., Hoshi, R. \& Hirata, A., (2003). Characterization of polymer-enzyme complex as a novel biocatalyst for non-aqueous enzymology. Journal of Molecular Catalysis B: Enzymatic 22, 79 - 88. DOI: 10.1016/S1381-1177(03)00009-2.

19. Crepon, B., Jozefonvicz, J., Chytry, V., Rihova, B. \& Kopecek, J., (1991). Enzymatic degradation and immunogenic properties of derivatized dextrans. Biomaterials 12:550-4. DOI: 10.1016/0142-961(91)90049-G.

20. Lee, K.Y. \& Yuk, S.H., (2007). Polymeric protein delivery systems. Prog. Polym. Sci. 32, 669 - 697. DOI: 10.1016/ j.progpolymsci.2007.04.001.

21. Sinha, V.R. \& Kumria, R., (2001). Polysaccharides in colon-specific drug delivery. International Journal of Pharmaceutics 224, 19 - 38. DOI: 10.1016/S0378-5173(01)00720-7.

22. Sanz, V., de Marcos, S., Castillo, J.R. \& Galbán, J., (2005). Application of Molecular Absorption Properties of Horseradish Peroxidase for Self-Indicating Enzymatic Interactions and Analytical Methods. J Am Chem Soc. 127,1038 1048. DOI: $10.1021 / \mathrm{ja} 046830 \mathrm{k}$.

23. Veitch, N.C. \& Nigel, C., (2004). Horseradish peroxidase: a modern view of a classic enzyme. Phytochemistry 65, 249 - 259. DOI: 10.1016/j.phytochem.2003.10.022.

24. Wei, Y., Feng, X., Chen, X., Hou, W. \& Zhu, J. J., (2008). A super highly sensitive glucose biosensor based on Au nanoparticles-AgCl@polyaniline hybrid material. Biosens. Bioelectron. 23, 925 - 931. DOI: 10.1016/j.bios.2007.09.002.

25. Zhu, M., Jiang, Z. \& Jing, W., (2005). Fabrication of polypyrrole-glucose oxidase biosensor based on multilayered interdigitated ultramicroelectrode array with containing trenches. Sens. Actuators. B: Chem. 110, 382 - 389. DOI: 10.1016/j.snb.2005.02.036.

26. Topcu Sulak, M., Gokdogan, O., Gulce, A. \& Gulce, H., (2006). Amperometric glucose biosensor based on golddeposited polyvinylferrocene film on $\mathrm{Pt}$ electrode. Biosens. Bioelectron. 21, 1719 - 1726. DOI: 10.1016/j.bios.2005.08.008.

27. Iyer, P.V. \& Ananthanarayan, L., (2008). Enzyme stability and stabilization-Aqueous and non-aqueous environment. Process Biochemistry, 43, 1019 - 1032. DOI: 10.1016/ j.procbio.2008.06.004.

28. de la Casa, R.M., Sanchez-Montero, J.M. \& Sinisterra, J.V., (1998). Modification of hydrophilicity/hydrophobicity of the microenvironment of lipase of Candida rugosa by dextrans, Biotechnology Letters. 21, 123 - 128. DOI: 10.1023/A:1005426101080.

29. de la Casa, R.M., Guisan, J.M., Sanchez-Montero, J.M. \& Sinisterra, J.V., (2002). Modification of the activities of two different lipases from Candida rugosa with dextrans. Enzyme and Microbial Technology 30, 30 - 40. DOI: 10.1016/S0141-0229(01)00446-X.

31. Tanaka, M., Morimoto, A., Ishimori, K. \& Morishima, I., (1998). Structure-activity relation of horseradish peroxidases as studied with mutations at heme distal and proximal sites. Pure and Appl Chem. 70, 911 - 916.

32. Altikatoglu, M., Arioz, C., Basaran, Y. \& Kuzu, H., (2009). Stabilization of Horseradish Peroxidase by Covalent Conjugation with Dextran Aldehyde Against Temperature and ph Changes. Central Euorpean Journal of Chemistry. 7:3, 423 - 428. DOI: 10.2478/s11532-009-0041-z.

33. Jakopitsch, C., Regelsberger, G., Furtmüller, P.G., Rüker F., Peschek, G.A. \& Obinger, C., (2002). Engineering the proximal heme cavity of catalase-peroxidase. Journal of Inorganic Biochemistry 91, 78 - 86. DOI:10.1016/S0162-0134(02)00374-4.

34. Dilgimen, A. S., Mustafaeva, Z., Demchenco, M., Kaneko, T., Osada, Y. \& Mustafaev, M.. (2001) Water-soluble covalent conjugates of bovine serum albumin with anionic poly(N-isopropyl-acrylamide) and their immunogenicity. Biomaterials 22, 2383 - 2392. DOI: 10.1016/S01142-9612(00)00425-7.

35. Mislovicova, D., Masarova, J., Bucko, M. \& Gemeiner, P., (2006). Stability of penicillin $G$ acylase modified with various polysaccharides. Enzyme and Microb. Technol. 39, 579 - 585. DOI: 10.1016/j.enzmictec.2005.11.012. 